\title{
Societal Factors and Life Satisfaction: Evidence from Low Income Urban Societies in a Developing Country
}

\author{
${ }^{1 *}$ Chengedzai Mafini, ${ }^{2}$ Daniel Meyer \\ ${ }^{1}$ Vaal University of Technology, South Africa \\ ${ }^{2}$ North West University, Vaal Triangle Campus, South Africa \\ *chengedzai@hotmail.com
}

\begin{abstract}
This paper tested the influence of four societal factors, namely marital status, religion, age and gender on the life satisfaction of low income urban earners in a developing country. A survey was conducted using a sample consisting of 985 individuals drawn from three low income townships in Gauteng Province, South Africa. In order to measure life satisfaction the validated Satisfaction with Life Scale developed by Diener et al. (1985), was utilised. Associations between each societal factor and life satisfaction were tested using multiple regression analysis. Marital status was statistically insignificant $(\beta=0.058 ; P=0.170)$. All categories of religion were statistically significant, with Christianity $(\beta=0.424 ; \mathrm{P}=0.044)$ exerting the highest influence on life satisfaction. In terms of age, young adults demonstrated higher satisfaction with life than older adults, with young adults $(\beta=0.369 ; \mathrm{P}=0.019)$ exerting the highest influence on life satisfaction than other age categories. Gender was statistically insignificant $(\beta=0.059 ; \mathrm{P}=0.307)$ depicting that life satisfaction is not dependent on gender. The paper closes by drawing conclusions based on the results and suggesting several policy implications for improving the impact of each societal factor on life satisfaction.
\end{abstract}

Keywords: Life satisfaction, marital status, religion, age, gender

\section{Introduction and background to the study}

As South Africa continues on its democratic adventure, major hassles remain that merit consideration from both researchers and practitioners. The South African societal fibre faces continuous strain as the golden generation of people that participated in the struggle against apartheid progressively succumbs to natural atrophy. Demographically, South Africa has evolved to become an ethnically and racially diverse African country, consisting of an assortment of both local people as well as those from various regions of the world who have come to settle there. This has made South Africa a complex entity in terms of its identity and social values. Coupled with this are massive cultural changes brought about by westernisation and technology. These have had the effect of diluting the traditionally acclaimed societal values of the different ethnic groups in the country. The influence of the existing unpredictable economic environment also comes to mind, with many decisions by people being based mostly on economic considerations than other factors. Accordingly, the nation's society has been caught up by such multifaceted developments, resulting in tectonic shifts whose effect on the well-being of society cannot be underestimated.

Life satisfaction remains one of the socio-economic indicators that may be employed to gauge the socio economic stability of any particular group of people (Oswald \& Powdthavee, 2008). Schatz et al. (2012) opine that life satisfaction is an important socio-economic pointer, since greater life satisfaction is linked to improved standards of living and general economic prosperity. In the context of South Africa, the socioeconomic developments on the ground invoke an interest to discover on a continuous basis the extent to which various groups of people are satisfied with life, and what factors, if any, are responsible for shaping whatever satisfaction patterns are observable. Additionally, as reported by Habib (2010), when developing policy initiatives, it is recommended that foci be directed to those that are on the lower income brackets as they are more likely to be in need than those on the upper income brackets. South Africa, despite being a developing country, has one of the highest gaps between the rich and the poor or is simply the country with arguably the greatest inequality, having the highest Gini coefficient the world over (Harmse, 2013). This creates an impetus to direct research attention to individuals and groups in low income urban societies since they experience the effects of this inequality on a daily basis. 
It is against the abovementioned background that this paper revisited the interlinkage between societal factors and life satisfaction. This paper aims to examine the influence of societal factors on the life satisfaction of people in low income urban societies. In order to achieve this aim, the following four objectives were formulated;

- To determine the effects of marital status on life satisfaction in low income urban societies in South Africa;

- To establish the effects of religion on life satisfaction in low income urban societies in South Africa;

- To determine the effects of age on life satisfaction in low income urban societies in South Africa;

- To establish the effects of gender on life satisfaction in low income urban societies in South Africa.

The study is significant in that its results can be used as a reference point by policy makers in developing countries in cultivating various initiatives aimed at improving well-being amongst residents of low income societies. The paper focuses exclusively on low income groups in urban societies, thereby acting as a scientific voice for such an important societal group. For researchers in development economics, the paper becomes an enduring source of literature on the interplay between societal factors and life satisfaction in developing countries such as those located in Africa South of the Sahara.

\section{Literature Review}

Life satisfaction: Satisfaction is generally considered to be the realisation of desires and goals stemming from being able to meet elementary physiological needs such as thirst, hunger, sex as well as spiritual wants that include success, curiosity, affection and love (Graham, 2014). The concept of life satisfaction was first introduced by Neugarten, Havighurst and Tobin (1961) and has evolved to become a hallmark idea in various fields. Perhaps due to its popularity and the level of interest it has generated among diverse scholars, there has been an avalanche of definitions associated with life satisfaction. However, this paper adopted Demirel's (2014) recent definition which states that life satisfaction is the emotional reaction of an individual outside his/her work life. Life satisfaction includes but is not limited to the general attitude of the individual towards life, being happy in daily life, feeling physically better-off, economic security and having well-fulfilling social relationships (Özer \& Sackes, 2011). Individuals normally assess their own range of life satisfaction levels based on presumed diverse standards and sets of criteria that meet their expectations (Lewis et al., 2011). More so, individuals tend to possess unique criteria that define what a good life is which may outweigh the common benchmarks of a good life, for example health and successful relationships (Suikkanen, 2011). This brings into effect the concept of global life satisfaction, which is a general evaluation of the quality of life that is in addition to judgements of distinct domains such as family and friends (Gilman \& Huebner, 2006).

Marital status and life satisfaction: Marriage is generally associated with improved satisfaction with life and well-being than other similar forms of relationships. There are several reasons why marriage is linked to higher life satisfaction. Kreider (2005) submits that it is considered beneficial for an individual's own identity to be able to stand on more than one leg. A case in point relates to the ability of marriage to provide supplementary sources of dignity, for instance, by emancipating people from stressful circumstances in other parts of life, such as at work (Willitts, Benzeval \& Stansfel, 2004). Frey and Stutzer (2006) support the existence of a positive rapport between marriage and individual satisfaction with life in the sense that marriage offers an extra source of self-respect and self-satisfaction. Married couples experience minimal loneliness and have the chance of benefiting from an understanding and intimate relationship from the significant other (Stanca, 2009). Furthermore, marriage epitomises a partnership that binds individuals to one another in a close connection that can reduce stress and be integrative socially (Cornman et al., 2003). Marriage is also renowned for its ability to provide important defensive blockades against the taxing aftereffects of external threats (Musick \& Bumpass, 2012). Marriage seems to confer societal incorporation to its participants, and provides them with a sense of belonging as well as a feeling of purpose, chiefly through folkbased social partnerships (Keyes \& Shapiro, 2004). Therefore, the benefits of marriage stand out through its position as an important model of social support (Shapiro \& Keyes, 2008).

Being married provides other advantages and incentives such as sharing in common household goods and the possibility of combined accumulation of both assets and wealth (Botha \& Booysen, 2012). Based on a micro- 
econometric well-being model, the impact of marriage on satisfaction with life has been deciphered into its monetary comparative. In the 1990s, some studies (Clark \& Oswald, 1994; Stack \& Eshleman, 1998) linked marriage to greater financial and health well-being, which contributes to increased life satisfaction. In a calculation by Blanchflower and Oswald (2008) it was observed that a lifelong marriage is usually worth USD100, 000 annually when compared to either being separated or widowed. The health benefits have also been statistically quantified. For instance, in the USA, a 1.5\% score was observed for married adults while unmarried adults scored $2.4 \%$, those divorced once scored 5.1\% and those in cohabitation scored 5.8\% in the calculation of the annual rate of major depression disorder Kay-Hymowitz et al., 2013). Based on these calculations, it is logical to assume that the economic benefits stemming from marriage far outstrip the opportunity costs, which leads to higher life satisfaction. In South Africa, a research by Powdthavee (2005) established that those in civil marriages demonstrated greater satisfaction with life than singles. Møller (2007) found that well-being was marginally greater among married South Africans in comparison to other marital status cohorts. Another study in South Africa by Botha and Booysen (2012) found that married couples were more satisfied with life when compared to those from all other marital status groups. These results are buttressed by studies in other contexts (Diener et al., 2000; Easterlin et al., 2010; Layard, 2006) which reported that people who are married consistently report greater satisfaction with life than those who are not married, such as individuals who have never married, or are divorced, separated and widowed. Thus, individuals who are not married experience less life satisfaction and are at a disadvantage when compared to their married counterparts.

Religion and life satisfaction: With the rise of secularism and globalisation, questions may arise on whether religion adds to or obstructs life satisfaction (Diener, Tay \& Myers, 2011). However, the most dominant view so far is that religion has a positive effect on satisfaction with life. As a case in point, some studies (Greeley \& Hout, 2006; Inglehart, 2010) found religion to be closely related to both satisfaction with life as well as happiness. On the reasons why religion leads to life satisfaction, Frey (2008) observed that regular attendance of church services is an influential basis of social sustenance for many people. Establishing a spiritual relation assures individuals that a stronger and higher supernatural power is always available to give them support (Tiliouine \& Belgoumidi, 2009). Religious people weather the storms of the adverse circumstances and disappointments more easily and suffer from less anxiety than non-religious people (Roshani, 2012). Neyrinck et al. (2006) add that religion plays a mediating role in influencing cognitive processes and appraisals of daily events by people. These authors further stress that individuals who actively participate in religious organisations live healthier and longer lives and are more satisfied with life than those who are not religious. Resultantly, even calamitous events may be construed as being positive when people link them to a positive role (Bradshaw, Ellison \& Flannelly, 2008). By influencing the attitudes of people towards past, present and future events in their lives, religious teachings and services are able to shape the ultimate levels of satisfaction with life amongst different people (Krause, 2006).

The fundamental question that remains controversial is whether the positive influence of religion on life satisfaction is applicable to every religion or if there exist certain differences amongst the religions (Greeley \& Hout, 2006). Each religion has its own distinctive ideals, social norms, values, rituals and further features that characterise it (Cohen, 2009). Due to these distinctions, the levels of life satisfaction in these religions are bound to vary (Cohen \& Johnson, 2013). In answering these questions, Filipić Perović and Kosor (2012) investigated satisfaction with life across a broad spectrum of religious denominations using a sample drawn from 144 countries representing 96\% of the world. Their study established that Catholic, Sunni- Muslim and Hindu adherents enjoy greater satisfaction with life when compared to the adherents of other denominations. Earlier on, Cohen and Hall (2009) established that Jews often report lower life satisfaction levels than people in other religions. Judgemental attitudes exhibited by Catholics and other Protestant groups often increase the guilt and shame on members to which they are directed, resulting in lower life satisfaction levels (Sheldon, 2006). However, Christians may experience higher well-being than some other religious groups in the sense that they experience a personal connection with God that has the effect of easing any feelings of solitude and social isolation (Epley et al., 2008; Johnson et al., 2011). Hence, religion plays a fundamental role in helping people to cope with their daily circumstances.

Age and life satisfaction: Empirical outcomes on the interconnection between age and satisfaction with life show a mixed bag of results, with some studies concluding that there is no relationship between the two 
constructs (e.g. Diener \& Seligman, 2004); some reporting an insignificant but linear association (e.g., Hansson, Hillerås \& Forsell, 2005) and some finding weak but inverse relationships (e.g. Chen, 2001). Still, others (Blanchflower \& Oswald, 2009: Easterlin, 2006; Gwozdz \& Sousa-Poza, 2010; Stone et al., 2010) report a curvilinear (U-shaped) relationship, with life satisfaction being lowest amongst individuals in middle age. In most economics literature that employs multivariate analysis (e.g. Clark \& Oswald, 2006; Clark et al., 2005; Lelkes, 2006) there is a general agreement on the predominance of a u-shaped trajectory, in which satisfaction with life reaches the minimum during middle age. This depicts that satisfaction with life is at its lowest during middle age (between 30 and 50 years) and highest during early life and later life. A common standpoint within the existent body of research is that satisfaction with life increases with age. Evidence gathered from a number of studies (Frijters \& Beatton, 2008; Gwozdz \& Sousa-Poza, 2010; Stone et al., 2010) advocates that people become more satisfied with life as they reach retirement and afterwards. Besides, older adults may experience greater satisfaction with their current lives as they acclimatise to the dwindling future possibilities in their lives (Carstensen, 2006; Lang, Baltes \& Wagner, 2007). Research conducted in South Africa by Powdthavee $(2003 ; 2005)$ provides further validation of the u-shaped relationship between age and life satisfaction. In analysing the results of a study by Yul and Gaibie (2011), one finds that older South Africans reported higher satisfaction with life than middle-aged South Africans. More recently, further endorsement of significant a u-shaped relationship between age and life satisfaction was found in a study by Ebrahim, Botha and Snowball (2013) that covered all racial groups in South Africa. These results make it rational to presuppose that older people in South Africa could be enjoying greater satisfaction with life than the younger generation.

Gender and life satisfaction: The universally acknowledged position on the gender-life satisfaction nexus is that women generally exhibit higher life satisfaction than men (Blanchflower \& Oswald, 2004; Frey, 2008; Van Praag \& Ferrer-i-Carbonell, 2008; Tiefenbach \& Kohlbacher, 2013). However, empirical findings in various environments seem to contradict this conventional position, which confounds the association existing between gender and satisfaction with life. For instance, a study by Stevenson and Wolfers (2009) spotlighted the paradox of declining life satisfaction in the USA. The study purports that over the past three decades, measures of life satisfaction indicate that women's satisfaction with life has declined absolutely and relatively to that of men. The study further forecasts that this decay is set to continue and a unique gender gap will emerge, in which men have higher satisfaction with life. In a previous study, Hayo and Seifert (2003) likewise found that Eastern European men were happier than women. In Asian countries a number of studies (Kusago, 2008; Ohtake, 2012; Sano \& Ohtake, 2007; Urakawa \& Matsuura, 2007; Tsuji, 2011) found gaps in the life satisfaction of men and women. Yamane, Yamane and Tsutsui (2008) found that gender does not influence life satisfaction. Still, Oshio (2011) found that life satisfaction is more narrowly linked to family as well as social relations for women than it is for men. In an Indian survey Jan and Masood (2008) disclosed that with an increase in incomes earned by families, the overall satisfaction with life of women tends to increase more rapidly than that of men. Amongst African Americans residing in the USA, women reported higher levels of religiosity and spirituality than their male counterparts, which correlates significantly with life satisfaction (Saundra \& Hughey, 2003). However, in contrast, some studies (e.g. Hinks \& Gruen, 2007; Mahadea \& Rawat, 2008) that were conducted in South Africa report no significant differences in satisfaction with life amongst gender groups. Also, in a Latin American survey conducted by Graham (2008) there were no significant differences in satisfaction with life observed between males and females. These divergent results denote that there is both a need as well as plenty of space for added research on the interconnection between gender and satisfaction with life, to uncover more recent permutations in this dynamic binary.

The survey: A survey was conducted in three townships (Sebokeng, Sharpville and Sicelo) areas located in the southern part of Gauteng Province in South Africa. The questionnaire elicited demographic information of respondents in the four societal domains (marital status, religion, age group and gender) under consideration in this investigation. Life satisfaction was measured using the five item-Life Satisfaction Scale (Diener et al., 1985). Using the availability sampling approach, a total of 1500 questionnaires were initially distributed in August 2014. However, 1323 questionnaires were returned. Among these, 338 questionnaires were discarded because they were spoilt, leaving a total of 985 observations that were utilised in the actual data analysis, giving a return rate of $66 \%$. A total of 298 respondents were drawn from Sebokeng, 285 were drawn from Sharpville and 402 respondents were drawn from Sicelo. The demographic distribution of respondents is disclosed in Table 1. 
Table 1: Demographic Profile of Respondents

\begin{tabular}{llllll}
\hline Marital Status & $\mathbf{N}$ & $\mathbf{\%}$ & Religion & $\mathbf{N}$ & $\mathbf{\%}$ \\
\hline Married & 323 & 32.8 & Christianity & 617 & 62.6 \\
Unmarried & 662 & 67.2 & African Tradition & 210 & 21.3 \\
Total & 985 & 100 & Other religions & 158 & 16.1 \\
& & & Total & 985 & 100 \\
Age Group & $\mathbf{N}$ & $\mathbf{\%}$ & Gender & $\mathbf{N}$ & $\mathbf{\%}$ \\
18-35 years & 431 & 43.7 & Male & 539 & 54.7 \\
36-50 years & 388 & 39.4 & Female & 446 & 45.3 \\
51+ years & 166 & 16.9 & Total & 985 & 100 \\
Total & 985 & 100 & & & \\
\hline
\end{tabular}

Table 1 shows that $39 \%(n=323)$ of the respondents were unmarried and $67 \%(n=662)$ were married. Further analyses indicates that the majority of respondents $(63 \%$; $n=617)$ were Christians followed by those affiliated to African traditions (21\%; $\mathrm{n}=210)$. After collapsing the age groups of respondents, it emerged that $44 \%(n=431)$ were aged between 18 and 35 years while $39 \%(n=388)$ were aged between 36 and 50 years and $17 \%(n=166)$ were aged above 51 years. In terms of gender, $55 \%(n=539)$ of the respondents were males and $45 \%(n=446)$ were females.

\section{Results}

Multiple regression analysis was employed as a means of testing for the contribution of the four societal domains in predicting life satisfaction. Using the enter method of regression, marital status, religion, age and gender were entered into the regression model as the independent variables and regressed against the dependent variable (life satisfaction). The study recognised that the data representing the variables to be tested were in the form of combination of categorical and continuous data. All four independent variables were categorical data while life satisfaction was in the continuous data configuration. In entering the data into the regression models, dummy variables were created for all categorical variables. Gender and marital status were entered into the regression models dichotomously (coded 0-1) since only two categories were recognised for both of them in this study. The age variable was entered into the regression models in three categories; namely, young adults (18-35 years), middle age (36-50 years and used as the reference group) and senior citizens (over 51 years). Three categories of religion; namely Christianity, African tradition (reference group) and Other Religions were entered into the regression models. A new variable, (Life satisfaction1) was computed and used to represent the life satisfaction variable in the regression analysis.

Regression analysis results: The results obtained in the regression analysis of the data collected from the three townships are reported in Table 2.

Table 2: Regression Analysis: Societal domains and life satisfaction

\begin{tabular}{|c|c|c|c|}
\hline \multirow{3}{*}{$\begin{array}{l}\text { Independent variables: Societal } \\
\text { factors }\end{array}$} & \multicolumn{3}{|c|}{ Dependent variable: Life satisfaction } \\
\hline & \multirow{2}{*}{$\begin{array}{l}\text { Beta } \\
(\beta)\end{array}$} & \multirow{2}{*}{$\begin{array}{l}\mathrm{T} \\
(\mathrm{t})\end{array}$} & \multirow{2}{*}{$\begin{array}{l}\text { Sig } \\
(P)\end{array}$} \\
\hline & & & \\
\hline Marital Status & 0.058 & 1.373 & 0.170 \\
\hline Religion: Christianity & 0.424 & 2.022 & 0.044 \\
\hline African Tradition: & Reference Group & 2.712 & 0.007 \\
\hline Other religions: & 0.214 & 2.555 & 0.011 \\
\hline Age Group :Young adults & 0.369 & 2.345 & 0.019 \\
\hline Middle age: & Reference Group & 2.721 & 0.007 \\
\hline Senior citizens & -0.142 & -3.421 & 0.001 \\
\hline Gender & 0.059 & 1.023 & 0.307 \\
\hline Adjusted $R^{2}=0.327$ & Significant at the .0 & & \\
\hline
\end{tabular}


In the Regression Model (Table 2), model fit was measured using the R-square, which is also known as the coefficient of determination. R-squared is a statistical measure of how close the data are to the fitted regression model and this is indicated by the percentage of variance (Friedman, 2012). The higher the percentage of variance accounted for by the regression model, the closer it is to a perfect model fit of $100 \%$ (Soyer \& Hogarth, 2011). The adjusted R-square value was 0.327 , which denotes that the societal factors considered in this study explained approximately $33 \%$ of the variance in satisfaction with life. In other words, the remaining $67 \%$ is accounted for by other extraneous factors that were not part of this study.

Discussion: The aim of this paper was to investigate the influence of societal factors on the satisfaction with life of people in low income urban societies. The discussion focuses on the results of the regression analysis regarding the individual effects of the four societal factors; marital status, religion, age and gender on life satisfaction.

Marital status and life satisfaction: In the regression analysis, marriage was statistically insignificant $(P$ $=0.170)$. The beta value for unmarried people was close to zero $(\beta=0.058)$, which testifies that the difference in life satisfaction for unmarried people when compared to married people is almost negligible and not statistically significant. This result demonstrates that marital status had no influence on the satisfaction with life of the residents of low income urban societies. This result is interesting because it contradicts several previous studies (e.g. Liu, Li \& Feldman, 2013; Musick \& Bumpass, 2012; Soons, Liefbroer \& Kalmijn, 2009; Stanca, 2009) which concluded that being married has a positive influence on satisfaction with life in different countries worldwide. The current study also contradicts studies previously conducted in South Africa (Botha \& Booysen, 2012, Møller, 2007; Powdthavee, 2005) which found that married people had better satisfaction with life than those in who are not married. In the present context, married people do not necessarily experience higher life satisfaction than those who are unmarried. The divergent results obtained in this study could be attributed to the view that amongst black people in South Africa, marriage as well as the concept of family are both quite complex. The South African society is characterised by sophisticated cultural diversities involving numerous ethnic orientations and age groups, each of which has a different view of marriage and its associated processes (Bordeaux, 2006). These different ethnic and age groups interpret marriage differently and practice it in varied ways. For instance, a study conducted by Mwambene and SlothNielsen (2011) found that marriage was far from universal among black South Africans, with cohabitation being more preferable and prevalent than either customary or civil marriage. The study further found that cohabiting individuals are generally considered to be single, but the practice is preferable among adults because it is easier to dissolve the relationship should need to do so arise. It is not surprising then that marriage is not accorded much of a high regard among groups who engender such values.

In addition to the aforementioned viewpoint, it also appears that the sanctity of the marriage institution is generally diluted in South Africa, as evidenced by the high divorce rate in the country. A case in point is that the number of marriages registered in South Africa has been on the decline since 2008 (Grant, 2015). Also, the National Health Marriage Resource Center (2015) reports that although the number of divorces occurring in South Africa has declined steadily over the years, it still has remained very high when compared to other countries, with South Africa being ranked number four on the list of countries with the highest divorce rates in the world. For instance, while 167,264 marriages were registered by the South African government in 2011 , a very high total of 20,980 divorces were recorded the same year, excluding the number of undocumented divorces or spousal breakups that occurred the same year (Statistics South Africa, 2012). This high divorce rate signals a lacklustre attitude towards marriage among South Africans, to the extent that people do not hesitate to relinquish the union if convinced that it necessary to do so. Thus, people seem to engender the perception that they have access to sources of life satisfaction other than marriage, which makes marriage less important to them.

Attitudes towards marriage in South Africa have also been negatively shaped by the decimation of South African families by the HIV/AIDS pandemic. According to Shisana et al. (2014) South Africa stands at the apex of HIV prevalence rankings worldwide, with an average of 400000 new HIV infections occurring every year and with a high death rate being the outcome. This has resulted in an epidemic of child-headed households and orphan-hood, which has left scores of children having to fend for themselves (Hosegood, 2009). Furthermore, , there has been an increase in the quantity of absent but living fathers, which makes single- 
parent families almost the custom within South Africa, whereby most of the children grow up under one parent who is most likely to be the mother (United Nations, 2011). On this subject Women's Wealth (2013) reports that about 53\% of working mothers in South Africa are single, while a survey by the South African Institute of Race Relations (2013) reports that $67 \%$ of the children in South Africa do not live with both their parents. Naturally, many such children possibly also grow up with uninspired attitudes towards the marriage institution, because they become accustomed to deriving satisfaction with life from sources other than the orthodox nuclear family. Therefore, the perception that marriage is an important source of life satisfaction may not exist amongst people who grew up under such fatherless circumstances.

Religion and life satisfaction: Three categories of religion (Christianity, African Tradition and other religions) were entered into the regression model. The results show that Christianity was both positively associated with life satisfaction $(\beta=0.418)$ and was statistically significant $(P=0.044)$ in predicting life satisfaction. This result indicates that Christians demonstrated higher life satisfaction when compared to those affiliated to the African Tradition. People in other religions also demonstrated higher life satisfaction ( $\beta$ $=0.211 ; P=0.007)$ when compared to those in the African Tradition. Overall, Christianity exerted a higher impact on life satisfaction than both African traditions and other religions. The positive beta values for Christianity and other religions designate that participating in religious activities tends to actuate higher levels of life satisfaction. These results are in sync with a study by Rule (2007) which found positive associations between religiosity and well-being amongst South Africans. Another study by Ebrahim et al. (2013) concluded that religious involvement contributes significantly to the well-being of South African Indians than other races. Thus, low income earners who are religious are more satisfied with life than those who are not religious.

As mentioned before, religious individuals tend to exhibit higher life satisfaction levels than those who do not attach value to religion (Barro \& McCleary, 2001; Greeley \& Hout, 2006; Sapienza \& Zingales, 2003; Mookerjee \& Beron, 2005). According to Crabtree and Pelham (2009) correlations have been observed between satisfaction with life and church attendance, religious attitudes, being close to God and the amount of time committed to religious activities. Religious people tend to excel at dealing with negative life situations and church members typically live healthier and longer lives, which also contributes to satisfaction with life (Filipić et al., 2012). Belief in God can inspire all that is morally upright in an individual, thereby stimulating the inner confidence to manage the demands of life maturely (Frijns, 2010). Still, religious experiences may provide a sense of meaning daily in life and during moments of major crises (Roemer, 2006). As observed by Krause (2006) people with more doubt about their religious faith tend to report lower satisfaction with life. In contrast, strong convictions in an individual's religious worldview, coupled with the belief that one qualifies to receive divine favour are linked to increased life satisfaction for some individuals (Green \& Elliott, 2010). These observations signify that religion is viewed as both a commanding coping system as well as a mechanism that provides meaning in one's life.

Age and life satisfaction: With regards to age, the results of the regression analysis communicate that young adults $(\beta=0.369$ : $P=0.019)$ had higher life satisfaction than those in middle age. Senior citizens demonstrated lower life satisfaction $(\beta=-0.142$ : $P=0.001)$ when compared to those in middle age. The negative beta associated with the senior citizen age cohort exemplifies that satisfaction with life decreases with an increase in age. The present study found that life satisfaction decreased with age, which implies that younger people were more satisfied than older people. These results contradict previous research results by several scholars (Blanchflower \& Oswald, 2008; Blanchflower \& Oswald, 2009; Gwozdz \& Sousa-Poza, 2010) that endorsed the "u-shaped" age-life satisfaction relationship. The results of the current study imply that the influence of age on satisfaction with life is grossly contextual and the $\mathrm{u}$-shape perspective is not a universal pattern. While in other environments life satisfaction tends to increase with age, the same does not hold true in the lexicon of low income earners in South Africa.

In order to decrypt the possible reasons why younger people are happier in South Africa, it is necessary to examine the contemporary lifestyle of South African youths. The youths of today enjoy high levels of relative peace and freedoms which were non-existent during the apartheid period. For example, discrimination and segregation are not known to these young people because they have grown up in a democratic dispensation where basic human rights are receiving major emphases. A survey by the Kaiser Family Foundation (2013) 
shows that the majority of youth in South Africa have a plethora of leisure activities at their disposal. The survey reveals that $69 \%$ of young South Africans watch television at least five days of the week, with soap operas and sports topping the list of favourite programs being watched. The survey further shows that approximately $80 \%$ of young South Africans listen to radio programmes at least five times a week. The majority (up to 94\%) of youths are either in school or in higher/tertiary education and approximately 53\% have developed a habit of reading a book for studying at least five times each week. With the rise of the Internet and its associated amenities and technologies, up to $91 \%$ of South African youths are spending more time surfing the Internet for leisure each week. These activities exclude other life satisfaction boosting activities such as going to church, social networking, exercising or participating in sports as well as dating. Jephta (2013) reports that young people in South Africa emerged as the happiest in a survey focusing on young people in Sub-Saharan Africa. The survey further reports that young South Africans believe that their country has a bright future and are willing to invest their efforts for the economic development of the country. Therefore, despite the manifold challenges that the country continues to face, young people in South Africa remain optimistic and have at their disposal plenty of activities that enhance their life satisfaction.

Unlike their younger counterparts, older South Africans face several challenges that appear to militate against their well-being. Older South Africans witnessed and experienced first-hand the barbarity of the apartheid apparatus and how these were later subdued. At the dawn of democracy in 1994 many promises were made by government to make life easier for South Africans. However, it has been difficult for the government to deliver on many of its promises, to the disappointment and frustration of many South Africans to whom such promises were made. For instance, even the social welfare system, which is expected to benefit most elderly South Africans, is under strain. Although pensioners aged above 65 years of age are entitled to monthly payouts from the South African Social Security Agency, the value of the amounts received has been severely eroded through inflationary pressures facing South Africa. The negative effects of these widespread challenges on life satisfaction cannot be underestimated. Although the entire nation is affected by these challenges, older people are more affected because they understand the history of the country and the promises made to the masses in the aftermath of apartheid. Some of the older people were active participants in the struggle for democracy, yet they have not been spared the hardships facing the country. It is possible then that the dissatisfaction experienced by such older people will be higher than that experienced by younger people in South Africa.

Gender and life satisfaction: With reference to gender the score obtained for males was not statistically significant $(P=0.307)$. The beta was very close to zero $(\beta=0.059)$ thereby portraying that life satisfaction for males was only slightly higher when compared to that for females. In view of this result, the current study offers the unique insight that gender does not predict life satisfaction. The result contradicts the claim by mainstream research results (e.g. Blanchflower \& Oswald, 2008; Van Praag \& Ferrer-i-Carbonell, 2008) that women are commonly more satisfied with life than their male counterparts. In order to decipher possible reasons for this result, it is necessary to revisit both the historical and contemporary contexts of gender roles in South Africa and diagnose how these have influenced attitudes towards life satisfaction. Historically, the existing cultures as well as the apartheid political machinery in South Africa regarded women as either less important or unworthy to enjoy equal benefit with men, leading to their marginalisation. The post-apartheid political dispensation came up with a cocktail of initiatives to address these historical gender imbalances, leading to a flood of opportunities for black women in South Africa. A report by the World Economic Forum (2013) expresses that by 2013, South Africa was ranked $17^{\text {th }}$ out of 136 countries in terms of gender equality, which depicts great strides in equalising gender roles in the country. In addition, many women in South Africa have been seconded to ministerial, parliamentary and other high ranking positions in government and the private sector (International Women's Forum, 2011). These positive developments reflect a steady move towards increased representation of women in public domains as well as a more equitable sharing of power throughout the country.

Despite these positive developments it still remains difficult to prove that these improvements apply to all groups of black females in the country. For example, evidence is still needed which shows that that these changes have had an equally positive effect on the lives of women in low income societies. It is paradoxical that on the one hand, some privileged South African females are enjoying the benefits created by attempts to bring about gender parity in the country; while on the other hand, hordes of females in the same country are 
still impoverished. It appears to be a case of extraordinary opulence in coexistence with extreme marginalisation in modern South Africa. This is supported by the results of a survey conducted by Smith (2015) which reveal that at least $64 \%$ of South African women perceive that the government has not done enough to empower women. Smit and Du Plessis (2011) further acknowledge that women in South Africa are still subjected to vices that include sexual harassment, forced labour, violence, marginalisation and various other forms of discrimination. It is obvious that, on a balance of probabilities, black women residing in townships are more vulnerable to these depravities than those residing elsewhere. When these circumstances are taken into consideration, it becomes difficult for women living under such circumstances to demonstrate greater satisfaction of life than men. It also becomes difficult for men who witness such manipulation and exploitation of women to perceive that the women can be any more satisfied with life than men.

\section{Conclusion}

The aim of this paper was to decode the influence of societal factors on the life satisfaction of residents of low income urban societies in a developing country. To achieve this aim, the study tested the influence of four societal factors; marital status, religion, age and gender on life satisfaction, using data collected from three low income townships in urban South Africa. The results of the study show that marital status has no influence on life satisfaction, as there were no significant differences in the life satisfaction of both married and unmarried individuals. Religion exerted a positive influence on life satisfaction, implying that people who are religious are more satisfied with life than those who are not religious. Christians enjoyed the greatest life satisfaction when compared to other religions. With reference to age, the study defied the conventional ushape view of the age-life satisfaction nexus by revealing that younger age groups were more satisfied with life than the elderly, with young adults exhibiting the highest levels of satisfaction. Moreover, contrary to the dominant traditional view that women are generally happier than males, gender had no influence on life satisfaction, implying that both male and female could experience somewhat similar satisfaction levels.

Contributions and implications of the study: This study contributes to the body of knowledge in the area of development economics by providing current insights on both literature and research methodologies. In this manner the paper may be used as a reference source by future researchers on similar matters. Furthermore, in terms of the influence of societal factors on satisfaction with life, the study contributes to the long-standing controversies directed to the interplay between each social factor considered in this study and satisfaction with life. The study reminds academics that it is unscientific to generalise the influence of each factor on satisfaction with life, since there are contextual factors that should be considered. Thus, whilst the subject may be inundated with domineering theoretical formulations, none of them has universal applicability.

The results of this paper are not without policy implications. Regardless of the fact that the study concluded that marital status had no influence on life satisfaction, it is still necessary to promote faithfulness in marriages between people in South Africa, taking into cognisance the long acknowledged benefits of being married and how these have led to increases in life satisfaction in other environments. Since the results obtained in this study were attributed to attitudes that are based on the dominant cultures in African communities in South Africa, the solution then could be to generate initiatives that lead to paradigmatic and cultural shifts regarding marriage among such groups. This responsibility primarily falls under the jurisdiction of the Department of Social Development, which can partner with Faith-Based Organisations (FBO) (e.g., churches), Community Based Organisations (CBOs) and other non-governmental organisations to develop and implement intensive educational campaigns that promote the virtues of faithfulness in marriage to people in townships. Once such values are embraced, more long-lasting marriages are bound to occur in which people stay faithful to each other and enjoy all of the benefits associated with marriage. Such benefits include inter alia, decreased prevalence of HIV/AIDS related infections, emotional support, social support and better financial organisation. In this manner marital status is likely to regain its prominence as a stimulant of higher life satisfaction amongst low income societies.

South Africa should forge ahead with the promotion of religious freedom as enshrined in the country's constitution. However significant gains can only be realised from religion if policy initiatives are drawn up that protect citizens against religious abuse. For instance, in the African Tradition, numerous deaths are 
reported each year as adolescent youths are forced to undergo the ritualistic initiations for transitioning from boyhood to manhood. On a similar note, the Christian religion has witnessed the mushrooming of Pentecostal denominations that coerce members to participate in some strange rituals such as drinking petrol and eating poisonous reptiles, all in the name of religion. Moreover, South Africa is not invulnerable to the vices of Islamic extremism. Such religious excesses only serve to hurt the adherents ultimately. This makes it necessary for policy makers to review this matter with the aim of coming up with appropriate measures of ensuring that people are protected from the overindulgences of religion and that only the positive benefits are derived from religious practices.

Since the study unearthed that younger people seem to be more satisfied with life than elderly people, it is necessary to generate initiatives for increasing satisfaction with life amongst the elderly in low income societies in South Africa. A more acceptable scenario would be to have reasonable life satisfaction levels across all age groups in South Africa. The financial support given by government to elderly people in the country should always be inflation-adjusted as this will ensure that it has sufficient value to sustain their livelihoods. In addition, the system used in the disbursement of such aid should be more equitable; catering even for those who are eligible to receive these funds, but are somehow not currently receiving these funds. The concessions received by the elderly should traverse other domains of life, such as massive discounts, and sometimes even free service in such areas as public transport, health and social support through free accommodation at nursing homes and government-paid care-givers. Some European countries, with the United Kingdom being a specific example, have managed to implement such systems successfully (Windle, Francis \& Coomber, 2011). Through these arrangements the welfare of the elderly becomes the primary responsibility of government, and this, coupled with the actions of responsible family members, is bound to make the lives of elderly people more comfortable, leading to higher life satisfaction.

Although the study showed that gender does not exert an influence on satisfaction of life, it is recognised that more still needs to be done to ensure gender parity in South Africa. The study acknowledges the efforts made so far by the South African government to improve the status of black women in the country. From a legislative angle, these strides include the Basic Conditions of Employment Act of 1998, The Choice of Termination of Pregnancy Act of 1997, the Domestic Violence Act and the Maintenance Act of 1998, the Customary Marriages Recognition Act of 1998, the Customary Law Act of 1998, The Employment Equity Act of 1999, the Skills Development Act of 1999, and The National Policy Framework on Women's Empowerment and Gender Equality of 2000 (Gauteng Provincial Government, 2013:6). However, despite such considerable progress towards improving the legal status of women, it is noteworthy that both South African women as well as men still do not enjoy equal rights in reality, more than twenty years after the emergence of democracy in the country. This study advances that it is not the lack of policy engineering but rather the lack of effective policy implementation, monitoring and evaluation that continues to hamper progress in the issue of gender equality in South Africa. This makes training and development on policy implementation, monitoring and evaluation an imperative for all individuals and groups in government. Where such training and development has been implemented but the lack of willpower is found to be the problem, it is necessary for the culprits to be relieved of their duties for the benefit of the nation.

\section{References}

Barro, R. \& McCleary, R. (2001). Religion, economy, and society in an international panel. Religion-Factor Research: Personal and Social Transformation Symposium at University of Pennsylvania.

Blanchflower, D. G. \& Oswald, A. J. (2004). Money, sex and happiness: an empirical study. Scandinavian Journal of Economics, 106(3), 393-415.

Blanchflower, D. G. \& Oswald, A.J. (2008). Is well-being U-shaped over the life cycle? Social Science and Medicine, 66, 1733-1749.

Blanchflower, D. G. \& Oswald, A. J. (2009). The U-shape without controls: a response to Glenn. Social Science and Medicine, 69(4), 486-488.

Botha, F. \& Booysen, F. (2012). The relationship between marital status and life satisfaction among South African adults. Acta Academica, 45(2), 150-170.

Bordeaux, D. (2006). South Africa's tribal traditions prevent new freedoms. The World \& I., 21(3), 6-15.

Bradshaw, M., Ellison, C. G. \& Flannelly, K. J. (2008). Prayer, God imagery, and symptoms of psychopathology. Journal for the Scientific Study of Religion, 47, 644-59. 
Carstensen, L. L. (2006). The influence of a sense of time on human development. Science, 312, 1913-1915.

Chen, C. (2001). Aging and life satisfaction. Social Indicators Research, 54, 57-79.

Clark, A. E. \& Oswald, A. J. (1994). Unhappiness and unemployment. Economic Journal, 104, 648-59.

Clark, A. E., Etilé, F. Postel-Vinay, C. Senik, C. \& Van der Straeten, K. (2005). Heterogeneity in reported wellbeing: evidence from twelve European countries. The Economic Journal, 115, 118-132.

Clark, A. E. \& Oswald, A. J. (2006). The Curved Relationship between Subjective Well-Being and Age. PSE Working Paper No 2006-29.

Cohen, A. B. (2009). Many forms of culture. American Psychologist, 64(3), 194-204.

Cohen, A. B. \& Johnson, K. A. (2013). Religion and well-being. A paper presented at the Yale Center for Faith and Culture consultation on Happiness and Human Flourishing, sponsored by the McDonald Agape Foundation, November 20-21. New Haven, Connecticut, USA.

Cohen, A. B. \& Hall, D. E. (2009). Existential beliefs, social satisfaction, and well-being among Catholic, Jewish, and Protestant older adults. International Journal for the Psychology of Religion, 19, 39-54.

Cornman, J. C., Goldman, N., Glei, D. A., Weinstein, M. \& Chang, M. C. (2003). Social ties and perceived support: two dimensions of social relationships and health among the elderly in Taiwan. Journal of Aging and Health, 15, 616-644.

Crabtree, S. \& Pelham, B. (2009). Religion Provides Emotional Boost to World's Poor. http://www.gallup.com/poll/116449/religion-provides-emotional-boost-world-poor.aspx. Date of access: 15 Dec 2014.

Demirel, H. (2014). An investigation of the relationship between job and life satisfaction among teachers. Procedia - Social and Behavioral Sciences, 116, 4925-4931.

Diener, E. D., Emmons, R. A., Larsen, R. J. \& Griffin, S. (1985). The satisfaction with life scale. Journal of Personality Assessment, 49(1), 71-75.

Diener, E., Gohm, C. L., Suh, E. \& Oishi, S. (2000). Similarity of the Relations between Marital Status and Subjective Well-Being across Cultures. Journal of Cross-Cultural Psychology, 3(4), 419-436.

Diener, E., Tay, L. \& Myers, D. (2011). The religion paradox: if religion makes people happy, why are so many dropping out? Journal of Personality and Social Psychology, 10(1/6), 1278-1290.

Diener, E. D. \& Seligman, M. (2004). Beyond money: toward an economy of well-being. Psychological Science in the Public Interest, 5, 1-31.

Ebrahim, A., Botha, F. \& Snowball, J. (2013). Determinants of life satisfaction among race groups in South Africa. Development Southern Africa, 30(2), 168-185.

Easterlin, R. A. (2006). Life cycle happiness and its sources: Intersections of psychology, economics, and demography. Journal of Economic Psychology, 27, 463-482.

Easterlin, R. A., McVey, L. A., Switek, M., Sawangfa, O. \& Zweig, J. S. (2010). The happiness-income paradox revisited. Proceedings of the National Academy of Sciences, 107(52), 224-263.

Epley, N., Akalis, S., Waytz, A. \& Cacioppo, J. T. (2008). Creating social connection through inferential reproduction: loneliness and perceived agency in gadgets, gods, and greyhounds. Psychological Science, 19(2), 114-120.

Filipić, P., Perović, L. M. \& Kosor, M. M. (2012). The relative importance of religious denominations for life satisfaction. http://www.happinesseconomics.net/ocs/index.php/heirs/ market happiness/paper/view/237/115. Date of access: 21 October 2014.

Frey, B. S. \& Stutzer, A. (2006). Does marriage make people happy or do happy people get married? The Journal of Socio-Economics, 35, 326-347.

Frey, B. S. (2008). Happiness: a revolution in economics. Cambridge, Massachusetts: MIT Press.

Friedman, J.H. (2012). Fast sparse regression and classification. International Journal of Forecasting, 28(3), 722-738.

Frijters, P. \& Beatton, T. (2008). The Mystery of the U-Shaped Relationship between Happiness and Age. NCER Working Paper 26.

Frijns, M. (2010). Determinants of life satisfaction: a cross-regional comparison. Masters dissertation. School of Business and Economics. Maastricht University. Netherlands.

Graham, M. C. (2008). Measuring Quality of Life in Latin America: What Happiness Research Can (And Cannot) Contribute. Inter-American Development Bank Research. Department Working Paper 649, Washington, DC.

Graham, M. C. (2014). Facts of Life: Ten Issues of Contentment. Parker, Colorado: Outskirts Press. 
Grant, L. (2015). 10 things about marriage in South Africa. Mail and Guardian. 19 May. http://mg.co.za/data/2015-05-19-10-things-about-marriage-in-south-africa-1. 20 May 2015

Greeley, A. \& Hout, M. (2006). Happiness and lifestyle among conservative Christians: the truth about conservative Christians. Chicago, Illinois: University of Chicago Press.

Gilman, R. \& Huebner, E. S. (2006). Characteristics of adolescents who report very high life satisfaction. Journal of Youth and Adolescence, 35, 311-319.

Guiso, L., Sapienza, P. \& Zingales, L. (2003). People's opium? Religion and economic attitudes. Journal of Monetary Economics, 50(1), 225-282.

Gwozdz, W. \& Sousa-Poza, A. (2010). Ageing, health and life satisfaction of the oldest old: an analysis for Germany. Social Indicators Research, 97, 397-417.

Habib, A. (2010). The state of the nation and its public service in contemporary South Africa: a critical reflection. Administration Publica, 18(3), 2-24.

Hansson, A., Hillerås, P. \& Forsell, Y. (2005). Well-being in an adult Swedish population. Social Indicators Research, 74, 313-325.

Harmse, L. (2013). South Africa's Gini Coefficient: causes, consequences and possible responses. Master's Dissertation. Gordon Institute of Business Studies. University of Pretoria. South Africa. http://repository.up.ac.za/bitstream/handle/2263/40181/Harmse_South_2013.pdf?sequence=1Dat e of access: 24 May 2015.

Hayo, B. \& Seifert, W. (2003). Subjective economic well-being in Eastern Europe. Journal of Economic Psychology, 24, 329-348.

Hinks, T. \& Gruen, C. (2007). What is the structure of South African happiness equations? Evidence from quality of life surveys. Social Indicators Research, 82:311-336.

Hosegood, V. (2009). The demographic impact of HIV and AIDS across the family and household life-cycle: Implications for efforts to strengthen families in sub-Saharan Africa. AIDS Care, 21, 13-21.

Inglehart, R. F. (2010). Faith and freedom: traditional and modern ways to happiness. In Diener, E.D., Helliwell, J.F. \& Kahneman, D (Eds). International differences in well-being. New York: Oxford University Press. pp. 351- 397.

International Women's Forum. (2011). The status of women in South Africa. A Preliminary Report Incorporating the Findings of Consultative Roundtable Discussions on Women Empowerment in South Africa. Https. Date of access: 21 May 2015.

Jan, M. \& Masood, T. (2008). An assessment of life satisfaction among women. Studies in Home Community Science, 2(1), 33-42.

Jephta, A. (2013). Young South Africans are the Happiest in Sub Saharan Africa - But they Don't Feel Safe and Don't Like the Look of the Future!http://www.every1mobile.net/young-south-africans-are-thehappiest-in-sub-saharan-africa-but-they-dont-feel-safe-and-dont-like-the-look-of-the-future/. Date of access: 24 May 2015.

Johnson, K. A., White, A. E., Boyd, B. M. \& Cohen, A. B. (2011). Matzah, meat, milk, and mana: Psychological influences on religion-cultural food practices. Journal of Cross Cultural Psychology, 42, 1421-1436.

Kay-Hymowitz, J. S. Carroll, W., Bradford W. \& Kaye, K. (2013). The benefits and costs of delayed marriage in America. 2012. The national campaign to prevent teen and unplanned pregnancy. http://nationalmarriageproject.org/wp-content/uploads/2013/03/KnotYet-FinalForWeb.pdf. Accessed 15 April 2016.

Kaiser Family Foundation. (2013). Hot Prospects, Cold Facts. A Survey of South African Youth. https://kaiserfamilyfoundation.files.wordpress.com/2013/01/kff-lovelife_a.pdf. Date of access: 24 May 2015.

Keyes, C. L. M. \& Shapiro, A. (2004). Social well-being in the United States: a descriptive epidemiology. In O. G. Brim, C.D. Ryff, \& R.C. Kessler (Eds.), How Healthy Are We? A National Study of Well-Being a Midlife. University of Chicago Press. pp. 350-372.

Krause, N. (2006). Religious doubt and psychological well-being: a longitudinal investigation. Review of Religious Research, 47, 287-302.

Kreider, R. M. (2005). Number, timing, and duration of marriages and divorces: 2001. Current Population Reports, P70-97. Washington, DC: U.S. Census Bureau.

Kusago, T. (2008). Japan's development: what economic growth, human development and subjective wellbeing measures tell us about? Thammasat Economic Journal, 26(2), 88-116.

Layard, R. (2006). Happiness and public policy: A challenge to the profession. Economic Journal, 116, 24-33. 
Liu, H., Li, S. \& Feldman, M. W. (2013). Gender in marriage and life satisfaction under gender imbalance in China: the role of intergenerational support and SES. Social Indicators Research, 114(3), 915-933.

Lang, F. R., Baltes, P. B. \& Wagner, G. G. (2007). Desired lifetime and end-of-life desires across adulthood from 20 to 90: a dual-source information model. The Journals of Gerontology: Series B: Psychological Sciences and Social Sciences, 62, 268-276.

Lelkes, O. (2006). Tasting freedom: happiness, religion and economic transition. Journal of Economic Behavior and Organization, 59(2), 173-194.

Lewis, A. D., Huebner, E. S., Malone, P. S. \& Valois, R. F. (2011). Life satisfaction and student engagement in adolescents. Journal of Youth and Adolescence, 40, 249-262.

Mahadea, D. \& Rawat, T. (2008). Economic growth, income and happiness: an exploratory study. South African Journal of Economics, 76, 276-290.

Møller, V. (2007). Satisfied and dissatisfied South Africans: results from the general household survey in international comparison. Social Indicators Research, 81, 389-415.

Mookerjee, R. \& Beron, K. (2005). Gender, religion and happiness. The Journal of Socio-Economics, 34, 674-685.

Musick, K. \& Bumpass, L. (2012). Re-examining the case for marriage: union formation and changes in wellbeing. Journal of Marriage and Family, 74(1), 1-18.

Mwambene, L. \& Sloth-Nielsen, J. (2011). Benign accommodation? Ukuthwala, 'forced marriage' and the South African Children's Act. African Human Rights Law Journal, 11(1), 1-22.

National Healthy Marriage Resource Center. 2015. Marriage Trends in Africa: A Fact Sheet. http://www.healthymarriageinfo.org/index.aspx. Date of access: 20 May 2015.

Neugarten, B. L., Havighurst, R. J. \& Tobin, S. S. (1961). The measurement of life satisfaction. Journal of Gerontology, 16, 134-143.

Neyrinck, B., Vansteenkiste, M., Lens, W., Duriez, B. \& Hutsebaut, D. (2006). Cognitive, affective, and behavioral correlates of internalization of regulations for religious activities. Motivation and Emotion, $30,323-334$.

Ohtake, F. (2012). Unemployment and happiness. Japan Labor Review, 9(2), 59-74.

Oshio, T. (2011). Gender differences among elderly Japanese: importance of family and social relations for life satisfaction. RIETI Discussion Paper Series, 11-E-051.

Oswald, A. J. \& Powdthavee, N. (2008). Does happiness adapt? A longitudinal study of disability with implications for economists and judges. Journal of Public Economics, 92, 1061-1077.

Özer, B. U. \& Sackes, M. (2011). Effects of academic procrastination on college students' life satisfaction. Procedia Social and Behavioral Sciences, 12, 512-519.

Powdthavee, N. (2003). Happiness and the standard of living: the case for South Africa. Warwick Economic Research Papers No. 675. http://www.powdthavee.co.uk/resources/ handbook2006.pdf. Date of access: 8 Jul. 2014.

Powdthavee, N. (2005). Unhappiness and crime: evidence from South Africa. Economica, 72(587), 531-547.

Roemer, M. (2006). Do religious beliefs and membership affect life satisfaction and happiness in Japan? http://www.allacademic.com//meta/p_mla_apa_research_citation/1/0/4/5/7/pages104577/ p104577-1.php. Date of access: 15 Dec 2015.

Roshani, K. (2012). Relationship between religious beliefs and life satisfaction with death anxiety in the elderly. Annals of Biological Research, 3(9), 4400-4405.

Rule, S. (2007). Religiosity and quality of life in South Africa. Social Indicators Research, 81, 417-434.

Saundra, H. S. \& Hughey, A. (2003). African American Women at Mid-life. J African American Women, 18(2), 133-147.

Sano, S. \& Ohtake, F. (2007). Employment and Happiness. Nihon RôdôKenkyûZasshi, 558, 4-18.

Schatz, E., Gómez-Olivé, X., Ralston, M., Menken, J. \& Tollman, S. (2012). The impact of pensions on health and wellbeing in rural South Africa: does gender matter? Social Science and Medicine, 75(10), 1864-1873.

Soyer, E. \& Hogarth, R. M. (2011). The illusion of predictability: how regression statistics mislead experts. International Journal of Forecasting, 28(3), 695-711.

Shapiro, A. \& Keyes, C. L. M. (2008). Marital status and social well-being: are the married always better off. Social Indicators Research, 88, 329-346.

Sheldon, K. M. (2006). Catholic guilt? Comparing Catholics' and Protestants' religious motivations. International Journal for the Psychology of Religion, 16, 209-223.

Shisana, O., Rehle, T., Simbayi, L. C., Zuma, K., Jooste, S., Zungu, N., Labadarios, D. \& Onoya, D. (2014). South African National HIV Prevalence, Incidence and Behaviour Survey, 2012. Cape Town, HSRC Press. 
http://www.hsrc.ac.za/uploads/pageContent/4565/SABSSM\%20IV\%20 LE0\%20final.pdf. Date of access: 20 May 2015.

Smit, D. \& Du Plessis, V. (2011). Sexual harassment in the education sector. Potchefstroom Electronic Law Journal, 149(6), 173-217.

Smith, J. (2015). Gender equality a signature failure. IOL News. 8 March. http://www.iol.co.za/news/southafrica/gender-equality-a-signature-failure-1.1828655\#.VV458Pmqqkp. Date of access: 21 May 2015.

Soons, J. P. M., Liefbroer, A. C. \& Kalmijn, M. (2009). The long-term consequences of relationship formation for subjective well-being. Journal of Marriage and Family, 71(5), 1254-1270.

Stack, S. \& Eshleman, J. R. (1998). Marital status and happiness: a 17-nation study. Journal of Marriage and Family, 60(2), 527-536.

Stanca, L. (2009). With or without you? Measuring the quality of relational life throughout the world. Journal of Socio-Economics, 38(5), 834-842.

Statistics South Africa. (2012). Statistical Release P0307: Marriages and divorces, 2011. Statistics South Africa. 10 December 2012. http://www.statssa.gov.za/ publications/P0307/P03072011.pdf. Date of access: 19 May 2015.

Stevenson, B. \& Wolfers, J. (2009). The paradox of declining female happiness. American Economic Journal: Economic Policy, 1(2), 190-225.

Stone, A. A., Schwartz, J. E., Broderick, J. E. \& Deaton, A. (2010). A snapshot of the age distribution of psychological well-being in the United States. Proceedings of the National Academy of Sciences, 107, 9985-9990.

Suikkanen, J. (2011). An improved whole life satisfaction theory of happiness. International Journal of Wellbeing, 1(1), 149-166.

South African Institute of Race Relations. (2013). First Steps to Healing the South African Family.http://irr.org.za/reports-and-publications/occasional-reports/files/first-steps-to-healingthe-south-african-family-final-report-mar-2011.pdf. Date of access: 19 May 2015.

Tiefenbach, T. \& Kohlbacher, F. (2013). Happiness from the Viewpoint of Economics: Findings from Recent Survey Data in Japan. DIJ Working Paper 13/1. Tokyo. http://www.dijtokyo.org/publications/WP1301_Tiefenbach_Kohlbacher.pdf. Date of access: 12 Oct 2014.

Tiliouine, H. \& Belgoumidi, A. (2009). Health and subjective wellbeing in Algeria: a developing country in transition. Applied Research in Quality of Life, 4(2), 223-238.

Tsuji, T. (2011). Regional analysis of personal income and happiness: is there a regional gap in the relationship between personal income and happiness? Journal of Economics, 15(2), 1-24.

Urakawa, K. \& Matsuura, T. (2007). The effect of economic disparity and class mobility on life satisfaction. Seikatsu Keizaigaku Kenkyû, 26, 13-30.

United Nations. (2014). Composition of macro geographical (continental) regions, geographical sub-regions, and selected economic and other groupings. http://millenniumindicators. un.org/unsd/methods/m49/m49regin.htm.Date of access: 20 May 2015.

Willitts, M., Benzeval, M. \& Stansfel, S. (2004). Partnership history and mental health over time. Journal of Epidemiology \& Community Health, 58, 53-58.

Windle, K., Francis, J. \& Coomber, C. 2011. Preventing loneliness and social isolation: interventions and outcomes. Social care Institute for Excellence Research Briefing 39.

http://www.bristol.gov.uk/sites/default/files/documents/health_and_adult_care/health/SCIE2039 \%20-\%20Preventing\%20Loneliness_0.pdf. Date of access: 14 June 2015.

Women's Wealth. (2013). Single Mothers Take More Strain. http://www.fin24.com/WomensWealth/Empowerment/Single-mothers-take-more-strain-20130827. Date of access: 19 May 2015.

World Economic Forum. (2013). The Global Gender Gap Report. http://www3.weforum.org/docs/WEF_GenderGap_Report_2013.pdf\#page=20. Date of access: 21 May 2015.

Van Praag, B. M. S. \& Ferrer-i-Carbonell, A. (2008). Happiness quantified: a satisfaction calculus approach. Oxford: Oxford University Press.

Yamane, S., Yamane, S. \& Tsutsui, Y. (2008). Interregional Inequalities measured by Happiness. GCOE Discussion Paper Series 7.

Yul, D. D. \& Gaibie, F. (2011). Quality of life in post-apartheid South Africa. Politikon: South African Journal of Political Studies, 38(2), 231-256. 